\title{
ANALYSIS OF TELECOMMUNICATION CHANNEL SPECTRAL CHARACTERISTICS WITH BLOCK CODING AT A CONSTANT SPEED OF THE MESSAGE SOURCE
}

\author{
Leonid A. Uryvsky, Andriy A. Korniienko, Bohdan O. Shmigel \\ Institute of Telecommunication Systems \\ Igor Sikorsky Kyiv Polytechnic Institute, Kyiv, Ukraine
}

Background. The direction of development of modern electronic communication systems tends to increase the speed of information transmission. In turn, increasing the speed requires the use of additional resources of the communication channel and tools to maintain the specified reliability of the transmission under limited conditions. But resources are not free. That is why there is a need to establish a relationship between the conditions for reliable transmission in high-speed channels and the spectral and energy parameters of the information transmission system.

Objective. The purpose of the paper is to analyse and describe the effect of block noise-tolerant coding on the rate of transmission of symbols in the communication channel while ensuring the required reliability of information transmission at a constant speed of the message source by increasing the frequency involved.

Methods. The initial stage of the study is the presentation of system parameters in case of inaccurate transmission. Then a block redundant code is synthesized, which ensures the reliability of information transmission and the procedure of spreading the spectrum at a fixed speed of the message source is performed.

Results. Recommendations on the method of selecting coding parameters in the procedure of spreading the spectrum and provided that the speed of the message source is constant are formed.

Conclusions. Analysis of the possibilities of noise-tolerant coding at different energies of the communication channel under conditions of increasing the channel transmission rate at a fixed speed of the message source.

Keywords: speed; message source; reliability; noise immunity.

\section{Introduction}

With each passing day, consumer demand for the consumption of large amounts of information is only growing $[1,2]$. That is why all telecommunication systems, first of all, keep the direction of development in increasing the speed of information transmission. In this case, ensuring the necessary reliability of information transmission depends entirely on the specialist who configures the network and takes into account that with increasing information speed you need to attract additional resources of the communication channel: spectral, energy, time $[3,4]$. But resources are not free. Therefore, the profitability of the information system as a whole depends on the method of attracting additional resources $[5,6]$.

In this study, it is not necessary to sacrifice some frequency resource to ensure appropriate reliability. It was decided in advance that the procedure of expanding the frequency resource will be performed, so as to maintain a fixed speed of the message source at a given reliability $[2,7]$.

The main tool will be a universal algorithm for managing the situation in the communication channel $[3,8,9,10]$.
The aim of the study is to analyse the possibilities of block coding when the spectral characteristic of the communication channel channel transmission rate - is expanded. The requirements are:

- the reliability of the transfer must be at the level $p_{\text {біт }}=10^{-6}$;

- fixed speed of the message source $V_{S}$.

The object of the study is an excessive noise-tolerant code which ensures the necessary reliability of information transmission.

The subject of the study is a fixed speed of the source of messages by which we understand the limits of the found code at a certain energy of the communication channel.

\section{Analysis of transmission system parameters with good communication channel energy}

Suppose there is a data transmission system whose initial parameters are shown in Table 1.

Table 1 - Initial parameters of the data transmission system ( 1 case)

\begin{tabular}{|c|c|c|c|c|c|}
\hline $\boldsymbol{\alpha}, \boldsymbol{M H z}$ & $\boldsymbol{M o d}$. & $\boldsymbol{V}_{\boldsymbol{S}}, \boldsymbol{M b p s}$ & $\boldsymbol{h}^{2}, \boldsymbol{d B}$ & $\boldsymbol{p}_{\text {bit }}$ & $\boldsymbol{V}_{\boldsymbol{C}}, \boldsymbol{M b p s}$ \\
\hline 600 & $\begin{array}{l}\text { PSK } \\
-2\end{array}$ & 75 & 9,03 & $\begin{array}{c}3,17 \\
\cdot 10^{-5}\end{array}$ & 75 \\
\hline
\end{tabular}


It can be seen that the probability of error does not meet the requirements that we set for the study, namely the probability of bit error should be at the level of $10^{-6}$. It is necessary to ensure the reliability of the requirements [11], so we use coding, then check whether the capabilities of the selected code to ensure the specified reliability when expanding the spectrum, provided that the speed of the message source $[12,13]$. The main tool is the frequency resource, which we will increase.

The main encoding parameter we choose is the length of the code block. Let the code be of length $n=500$. Using the developed technique, determine the parameters of the transmission system using coding and enter in Table $2[3,14]$.

Table 2 - Parameters of the data transmission system with coding (1 case)

\begin{tabular}{|c|c|c|c|c|c|c|}
\hline $\begin{array}{c}\boldsymbol{V}_{\boldsymbol{C}}, \\
\boldsymbol{M b p s}\end{array}$ & $\boldsymbol{h}^{2}, \boldsymbol{d B}$ & $\begin{array}{c}\boldsymbol{p}_{\text {bit }} \\
\text { to cod. }\end{array}$ & $\boldsymbol{t}$ & $\begin{array}{c}\boldsymbol{p}_{\text {bit }} \\
\mathbf{a f t e r} \\
\text { cod. }\end{array}$ & $\boldsymbol{r}_{\boldsymbol{c}}$ & $\begin{array}{c}\boldsymbol{V}_{\boldsymbol{S}}, \\
\boldsymbol{M b p s}\end{array}$ \\
\hline 75 & 9,03 & $\begin{array}{c}3,17 \\
\cdot 10^{-5}\end{array}$ & 2 & $\begin{array}{c}6,5 \\
\cdot 10^{-7}\end{array}$ & 0,989 & 74,1 \\
\hline
\end{tabular}

Now, using the already found code, perform the operation of expanding the spectrum, namely increasing the data rate. At the same time, it is necessary to analyse whether there are enough possibilities (found parameters) of coding to ensure the reliability of the given energy of the communication channel.

To find out at what data rate use the following formula $[1,7]$ :

$$
V_{S}=V_{C} \cdot \log _{2}(M) \cdot r_{C}
$$

where $V_{S}-$ message source speed;

$V_{C}-$ channel transmission rate (frequency resource);

$M$ - multiplicity of modulation;

$r_{C}-$ coding speed.

$$
V_{S_{1}}=V_{C_{2}} \cdot 1 \cdot r_{C_{2}}=V_{C_{2}} \cdot 0,99
$$

According to the initial parameters of the transmission system $V_{S_{1}}=75 \mathrm{Mbps}$. When:

$$
V_{C_{2}}=\frac{V_{S_{1}}}{r_{C_{2}}}=\frac{75}{0,989}=75,86 \mathrm{Mbps}
$$

We will increase the rate of transmission of symbols in the communication channel and calculate all other parameters of the information transmission system, which will be entered in Table 3 .
Table 3 - Parameters after spectrum expansion ( 1 case)

\begin{tabular}{|c|c|c|c|c|c|c|}
\hline $\begin{array}{c}\boldsymbol{V}_{\boldsymbol{S}}, \\
\text { Mbps }\end{array}$ & $\begin{array}{c}\boldsymbol{V}_{\boldsymbol{C}}, \\
\mathbf{M b p s}\end{array}$ & $\begin{array}{c}\boldsymbol{h}^{2}, \\
\boldsymbol{d} \boldsymbol{B}\end{array}$ & $\begin{array}{c}\boldsymbol{p}_{\text {bit }} \\
\text { to cod. }\end{array}$ & $\boldsymbol{t}$ & $\begin{array}{c}\boldsymbol{p}_{\text {bit }} \\
\text { after } \\
\text { cod. }\end{array}$ & $\boldsymbol{r}_{\boldsymbol{c}}$ \\
\hline 75 & 75,86 & 8,98 & $\begin{array}{c}3,49 \\
\cdot 10^{-5}\end{array}$ & 2 & $\begin{array}{c}8,66 \\
\cdot 10^{-7}\end{array}$ & 0,989 \\
\hline
\end{tabular}

Let us display the solution of the corresponding problem graphically in Fig. 1 .

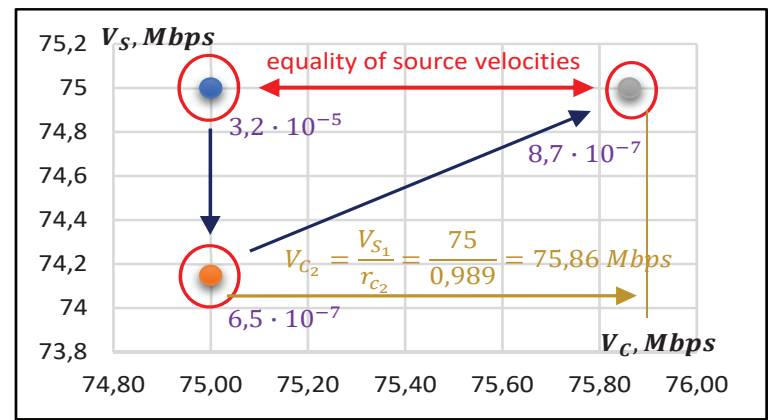

Fig. 1. Graphic display of 1 case

As you can see, the capabilities of the redundant code were enough to achieve the specified requirements for the reliability of the transmission and the condition of constancy of the transmission speed in the communication channel when expanding the spectrum.

Now you need to check the algorithm with a different energy channel.

\section{Analysis of transmission system parameters at average communication channel energy}

Under the average energy index we will consider the signal-to-noise ratio $h^{2}=$ $7 d B$ and $h^{2}=5 d B$, of course in relation to the modulation used $-F M-2$.

Let's increase the indicator that we record, namely the speed of the message source to $120 \mathrm{Mbps}$ and perform the calculation.

The initial parameters of the information transmission system in this case will be as follows:

Table 4 - Initial parameters of the data transmission system ( 2 cases)

\begin{tabular}{|c|c|c|c|c|c|}
\hline $\boldsymbol{\alpha}, \boldsymbol{M H z}$ & Mod. & $\boldsymbol{V}_{\boldsymbol{S}}, \boldsymbol{M b p s}$ & $\boldsymbol{h}^{2}, \boldsymbol{d B}$ & $\boldsymbol{p}_{\text {bit }}$ & $\boldsymbol{V}_{\boldsymbol{C}}, \boldsymbol{M b p s}$ \\
\hline \multirow{2}{*}{600} & $\begin{array}{c}\text { PSK } \\
-2\end{array}$ & 120 & 6,99 & $\begin{array}{l}7,83 \\
\cdot 10^{-4}\end{array}$ & 120 \\
\hline
\end{tabular}

Increasing the fixed speed of the message source has degraded the power in the communication channel to $6,99 d B$. Of course, the quality of transmission deteriorated immediately after energy. That is, in this case we can talk about the inaccuracy of information transmission more confidently, because the 
probability of error is already at the level of $10^{-4}$.

As in the previous experiment, we use the encoding $(n=500)$ to ensure the reliability of the transmission and enter all the parameters of the system with the encoding in Table 5.

Table $5-$ Parameters of the data transmission system with coding ( 2 cases)

\begin{tabular}{|c|c|c|c|c|c|c|}
\hline $\begin{array}{c}\boldsymbol{V}_{\boldsymbol{C}}, \\
M b p s\end{array}$ & $\boldsymbol{h}^{2}, \boldsymbol{d B}$ & $\begin{array}{c}\boldsymbol{p}_{\text {bit }} \\
\text { to cod. }\end{array}$ & $\boldsymbol{t}$ & $\begin{array}{c}\boldsymbol{p}_{\text {bit }} \\
\text { after } \\
\text { cod. }\end{array}$ & $\boldsymbol{r}_{\boldsymbol{c}}$ & $\begin{array}{c}\boldsymbol{V}_{\boldsymbol{S}} \\
\boldsymbol{M} \boldsymbol{b p s}\end{array}$ \\
\hline 120 & 6,99 & $\begin{array}{c}7,83 \\
10^{-4}\end{array}$ & 6 & $\begin{array}{c}1,9 \\
10^{-7}\end{array}$ & 0,959 & 115,13 \\
\hline
\end{tabular}

Table 5 shows how the parameters of the information transmission system change when the initial parameters deteriorate. Namely:

- deterioration of the initial probability of error leads to an increase in the correctness of the code (from 2 to 6 );

- increasing the correctness of the code affects its speed - it decreases. This means that more resources are given to coding.

Using formula 1, again determine how much to increase the channel rate so that the value of the speed of the message source remains unchanged.

$$
V_{S_{1}}=V_{C_{2}} \cdot 1 \cdot r_{C_{2}}=V_{C_{2}} \cdot 0,99
$$

According to the initial parameters of the transmission system $V_{S_{1}}=120$. When:

$$
V_{C_{2}}=\frac{V_{S_{1}}}{r_{c_{2}}}=\frac{120}{0,959}=125,08 \mathrm{Mbps}
$$

It is to this value that we need to expand our range. Similar to the previous paragraph, determine the parameters of the system after the expansion procedure and enter them in Table 6.

Table 6 - Parameters after spectrum expansion ( 2 cases)

\begin{tabular}{|c|c|c|c|c|c|c|}
\hline $\begin{array}{c}\boldsymbol{V}_{\boldsymbol{S}}, \\
\text { Mbps }\end{array}$ & $\begin{array}{c}\boldsymbol{V}_{\boldsymbol{C}}, \\
\text { Mbps }\end{array}$ & $\begin{array}{c}\boldsymbol{h}^{2}, \\
\boldsymbol{d B}\end{array}$ & $\begin{array}{c}\boldsymbol{p}_{\text {bit }} \\
\text { to cod. }\end{array}$ & $\boldsymbol{t}$ & $\begin{array}{c}\boldsymbol{p}_{\text {bit }} \\
\text { after } \\
\text { cod. }\end{array}$ & $\boldsymbol{r}_{\boldsymbol{c}}$ \\
\hline 120 & 125,08 & 6,81 & $\begin{array}{c}9,76 \\
\cdot 10^{-4}\end{array}$ & 6 & $\begin{array}{c}8,24 \\
\cdot 10^{-7}\end{array}$ & 0,959 \\
\hline
\end{tabular}

Let us display the solution of the corresponding problem graphically in Fig. 2.

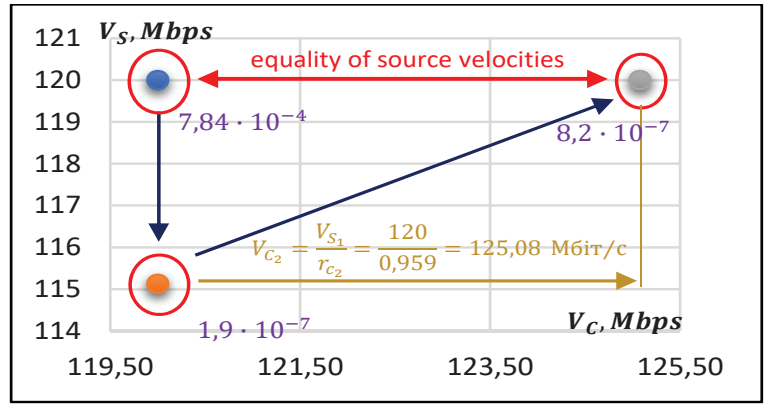

Fig. 2. Graphic display of 2 cases

The result of the second case shows that even with the deterioration of the initial parameters of the system, this procedure with fixing the speed of the message source with a given reliability copes after two steps at once. That is why the experiment is carried out in the direction of lowering the energy of the communication channel.

Let's move on to the third case, where we increase the speed of the message source to $190 \mathrm{Mbps}$ and fix it.

Table 7 - Initial parameters of the data transmission system (3 cases)

\begin{tabular}{|c|c|c|c|c|c|}
\hline $\boldsymbol{\alpha}, \boldsymbol{M H z}$ & $\boldsymbol{M o d}$. & $\boldsymbol{V}_{\boldsymbol{S}}, \boldsymbol{M b p s}$ & $\boldsymbol{h}^{2}, \boldsymbol{d B}$ & $\boldsymbol{p}_{\text {bit }}$ & $\boldsymbol{V}_{\boldsymbol{C}}, \boldsymbol{M b p s}$ \\
\hline 600 & $\begin{array}{c}\text { PSK } \\
-2\end{array}$ & 190 & 4,99 & $\begin{array}{l}5,98 \\
\cdot 10^{-3}\end{array}$ & 190 \\
\hline
\end{tabular}

In this case, the energy of the channel reaches the level of $4,99 \mathrm{~dB}$. In general, the initial state of the system is worse than in the second case. At once we will find coding parameters which will provide reliability and we will enter them in Table 8.

Table $8-$ Parameters of the data transmission system with coding (3 cases)

\begin{tabular}{|c|c|c|c|c|c|c|}
\hline $\begin{array}{c}\boldsymbol{V}_{\boldsymbol{C}}, \\
\text { Mbps }\end{array}$ & $\boldsymbol{h}^{2}, \boldsymbol{d B}$ & $\begin{array}{c}\boldsymbol{p}_{\text {bit }} \\
\text { to cod. }\end{array}$ & $\boldsymbol{t}$ & $\begin{array}{c}\boldsymbol{p}_{\text {bit }} \\
\text { after } \\
\text { cod. }\end{array}$ & $\boldsymbol{r}_{\boldsymbol{c}}$ & $\begin{array}{c}\boldsymbol{V}_{\boldsymbol{S}} \\
\boldsymbol{M b p s}\end{array}$ \\
\hline 190 & 4,99 & $\begin{array}{c}5,98 \\
\cdot 10^{-3}\end{array}$ & 14 & $\begin{array}{l}5,65 \\
10^{-7}\end{array}$ & 0,898 & 170,6 \\
\hline
\end{tabular}

Table 8 shows the constant dynamics, where the corrective power increases and the code speed decreases. Let's use formula 1 and find how much we need to expand our range. Data with calculations will be entered in Table 9.

$$
V_{C_{2}}=\frac{V_{S_{1}}}{r_{c_{1}}}=\frac{190}{0,898}=211,65 \mathrm{Mbps}
$$

Table 9 - Parameters after spectrum expansion (3 cases)

\begin{tabular}{|c|c|c|c|c|c|c|}
\hline $\begin{array}{c}V_{S}, \\
M b p s\end{array}$ & $\begin{array}{c}V_{C}, \\
M b p s\end{array}$ & $\begin{array}{c}h^{2}, \\
d B\end{array}$ & $\begin{array}{c}\boldsymbol{p}_{\text {bit }} \\
\text { to cod. }\end{array}$ & $t$ & $\begin{array}{c}\boldsymbol{p}_{\text {bit }} \\
\text { after } \\
\text { cod. }\end{array}$ & $\boldsymbol{r}_{c}$ \\
\hline
\end{tabular}




\begin{tabular}{|l|l|l|l|l|l|l|}
\hline 190 & 211,65 & 4,53 & $\begin{array}{l}8,63 \\
\cdot 10^{-3}\end{array}$ & 14 & $\begin{array}{l}4,17 \\
\cdot 10^{-5}\end{array}$ & 0,898 \\
\hline
\end{tabular}

Now, the fun begins. After analysing Table 9, it is possible to notice two main factors:

- similarly, to the previous cases the constancy of speed of a source of messages is provided;

- in this case, when expanding the spectrum using the already known code, the specified transmission reliability is not provided, because the bit error probability in this case is at the level of $10^{-5}$.

Having come to this situation, you need to take the following steps:

1) when the found code did not provide reliability, it is necessary to define parameters of new coding for a condition of system after expansion (by analogy to an initial condition);

2) perform re-expansion of the spectrum using the new code.

That is, you need to perform all the actions that were performed before, but assuming that the state of the system after expansion is in some sense initial.

First of all, find the encoding parameters that will ensure reliability and enter in Table 10.

Table 10 - Parameters of the data transmission system with coding (3 cases recalculation)

\begin{tabular}{|c|c|c|c|c|c|c|}
\hline $\begin{array}{c}\boldsymbol{V}_{\boldsymbol{C}}, \\
\text { Mbps }\end{array}$ & $\boldsymbol{h}^{2}, \boldsymbol{d B}$ & $\begin{array}{c}\boldsymbol{p}_{\text {bit }} \\
\text { to cod. }\end{array}$ & $\boldsymbol{t}$ & $\begin{array}{c}\boldsymbol{p}_{\text {bit }} \\
\mathbf{a f t e r} \\
\text { cod. }\end{array}$ & $\boldsymbol{r}_{\boldsymbol{c}}$ & $\begin{array}{c}\boldsymbol{V}_{\boldsymbol{S}} \\
\boldsymbol{M} \boldsymbol{b p s}\end{array}$ \\
\hline 211,65 & 4,53 & $\begin{array}{c}8,63 \\
\cdot 10^{-3}\end{array}$ & 17 & $\begin{array}{c}6,04 \\
\cdot 10^{-7}\end{array}$ & 0,874 & 185 \\
\hline
\end{tabular}

Now using the new code rate, we find the channel bit rate to which you want to extend.

$$
V_{C_{3}}=\frac{V_{S_{1}}}{r_{C_{2}}}=\frac{190}{0,874}=217,33 \mathrm{Mbps}
$$

Extend the frequency band to this level and using the second code found, define other system parameters and enter them in Table 11.

Table 11 - Parameters after spectrum expansion ( 3 cases - recalculation)

\begin{tabular}{|c|c|c|c|c|c|c|}
\hline $\begin{array}{c}\boldsymbol{V}_{\boldsymbol{S}}, \\
\text { Mbps }\end{array}$ & $\begin{array}{c}\boldsymbol{V}_{\boldsymbol{C}}, \\
\text { Mbps }\end{array}$ & $\begin{array}{c}\boldsymbol{h}^{2}, \\
\boldsymbol{d} \boldsymbol{B}\end{array}$ & $\begin{array}{c}\boldsymbol{p}_{\text {bit }} \\
\text { to cod. }\end{array}$ & $\boldsymbol{t}$ & $\begin{array}{c}\boldsymbol{p}_{\text {bit }} \\
\text { after } \\
\text { cod. }\end{array}$ & $\boldsymbol{r}_{\boldsymbol{c}}$ \\
\hline 190 & 217,33 & 4,41 & $\begin{array}{c}9,39 \\
\cdot 10^{-3}\end{array}$ & 17 & $\begin{array}{c}1,96 \\
10^{-6}\end{array}$ & 0,874 \\
\hline
\end{tabular}

It is possible to notice that after repeated actions the value of probability of an error approached the set requirements, but nevertheless is higher. Therefore, it is necessary to perform another recalculation and make sure that the result satisfies both requirements: consistency of the source speed and reliability at the level of $10^{-6}$.

Find the parameters of the new code and enter in accordance with Table 12.

Table 12 - Parameters of the data transmission system with coding ( 3 cases -2 nd recalculation)

\begin{tabular}{|c|c|c|c|c|c|c|}
\hline $\begin{array}{c}\boldsymbol{V}_{\boldsymbol{C}}, \\
M b p s\end{array}$ & $\boldsymbol{h}^{2}, \boldsymbol{d B}$ & $\begin{array}{c}\boldsymbol{p}_{\text {bit }} \\
\text { to cod. }\end{array}$ & $\boldsymbol{t}$ & $\begin{array}{c}\boldsymbol{p}_{\text {bit }} \\
\text { after } \\
\text { cod. }\end{array}$ & $\boldsymbol{r}_{\boldsymbol{c}}$ & $\begin{array}{c}\boldsymbol{V}_{\boldsymbol{S}} \\
\boldsymbol{M b p} \boldsymbol{s}\end{array}$ \\
\hline 217,33 & 4,41 & $\begin{array}{c}9,39 \\
10^{-3}\end{array}$ & 18 & $\begin{array}{c}4,64 \\
\cdot 10^{-7}\end{array}$ & 0,866 & 188,3 \\
\hline
\end{tabular}

Again, using the new code rate, we find the channel bit rate to which we want to extend.

$$
V_{C_{4}}=\frac{V_{S_{1}}}{r_{c_{3}}}=\frac{190}{0,866}=219,29 \mathrm{Mbps}
$$

We will increase the channel transmission rate to this value and determine all the parameters of the transmission system. The data are entered in Table 13.

Table 13 - Parameters after spectrum expansion ( 3 cases -2 nd recalculation)

\begin{tabular}{|c|c|c|c|c|c|c|}
\hline $\begin{array}{c}\boldsymbol{V}_{\boldsymbol{S}}, \\
\text { Mbps }\end{array}$ & $\begin{array}{c}\boldsymbol{V}_{\boldsymbol{C}}, \\
\boldsymbol{M b p s}\end{array}$ & $\begin{array}{c}\boldsymbol{h}^{2}, \\
\boldsymbol{d} \boldsymbol{B}\end{array}$ & $\begin{array}{c}\boldsymbol{p}_{\text {bit }} \\
\text { to cod. }\end{array}$ & $\boldsymbol{t}$ & $\begin{array}{c}\boldsymbol{p}_{\text {bit }} \\
\text { after } \\
\text { cod. }\end{array}$ & $\boldsymbol{r}_{\boldsymbol{c}}$ \\
\hline 190 & 219,29 & 4,37 & $\begin{array}{c}9,66 \\
10^{-3}\end{array}$ & 18 & $\begin{array}{c}7,03 \\
10^{-7}\end{array}$ & 0,866 \\
\hline
\end{tabular}

For greater clarity, we will represent this case graphically in Fig. 3.

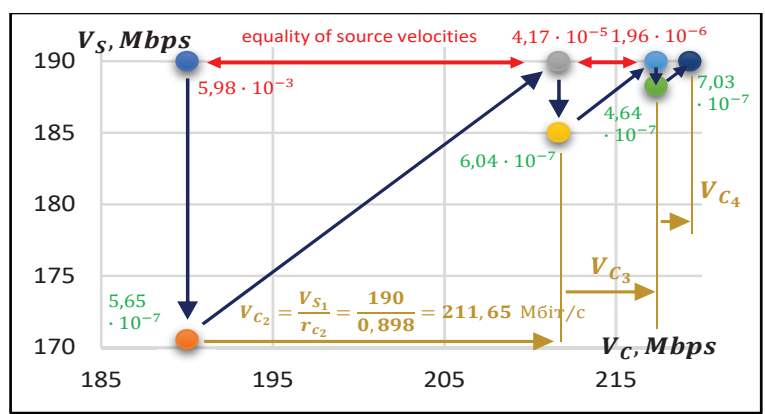

Fig. 3. Graphic display of 3 cases

According to Fig. 3, we can conclude that to find a noise-tolerant code that will ensure the condition of constant speed of the message source and ensure reliability using an additional frequency resource, it was necessary to perform the actions presented in cases $1-2$, but several times.

In other words, the smaller the initial power reserve of the transmission system, the more cyclic actions to find the code parameter and increase the frequency resource will need to be reproduced.

Let's check this statement in the next paragraph. 


\section{Analysis of transmission system parameters at low communication channel energy}

We will conduct a similar analysis, but at low energy. Under low energy we understand the level of the signal-to-noise ratio $h^{2}=3 d B$.

In the last paragraph, it was emphasized that at low energy the number of cyclical operations is likely to increase, so we will not describe the actions in detail, as they have already been described above.

We present a table with calculations of the parameters of all states of the transmission system, such as above. And in the end, we give a graphical representation of the solution of the problem.

In this case, there will be only one table with the data obtained after the cyclic steps described above. The main goal of this experiment is to count the number of cyclic operations, if possible. Because it is possible that this operation can be done indefinitely and it will not work. In this situation, you need to develop recommendations for further action.

Table 14 - Parameters after spectrum expansion (4 cases - generalized table of states)

\begin{tabular}{|c|c|c|c|c|c|c|c|}
\hline $\begin{array}{l}\text { № of } \\
\text { state }\end{array}$ & $\begin{array}{c}V_{S}, \\
\text { Mbps }\end{array}$ & $\begin{array}{l}h^{2}, \\
d B\end{array}$ & $\begin{array}{c}\boldsymbol{V}_{C}, \\
\text { MMbps }\end{array}$ & $\begin{array}{c}p_{\text {bit }} \\
\text { Before } \\
\text { coding }\end{array}$ & $t$ & $\begin{array}{c}p_{b i t} \\
\text { After coding }\end{array}$ & $r_{c}$ \\
\hline 1 & 300 & 3 & 300 & $2,3 \cdot 10^{-2}$ & & & \\
\hline 2 & 231,6 & 3 & 300,0 & $2,3 \cdot 10^{-2}$ & 30 & $7,9 \cdot 10^{-7}$ & 0,77 \\
\hline 3 & 300 & 1,9 & 388,7 & $3,9 \cdot 10^{-2}$ & 30 & $9,9 \cdot 10^{-3}$ & 0,77 \\
\hline 4 & 260 & 1,9 & 388,7 & $3,9 \cdot 10^{-2}$ & 43 & $9,3 \cdot 10^{-7}$ & 0,67 \\
\hline 5 & 300 & 1,3 & 448,5 & $5,1 \cdot 10^{-2}$ & 43 & $3,7 \cdot 10^{-4}$ & 0,67 \\
\hline 6 & 268 & 1,3 & 448,5 & $5,1 \cdot 10^{-2}$ & 52 & $5,6 \cdot 10^{-7}$ & 0,60 \\
\hline 7 & 300 & 0,8 & 502,2 & $6,1 \cdot 10^{-2}$ & 52 & $8,2 \cdot 10^{-5}$ & 0,60 \\
\hline 8 & 272,1 & 0,8 & 502,2 & $6,1 \cdot 10^{-2}$ & 59 & $6,2 \cdot 10^{-7}$ & 0,54 \\
\hline 9 & 300 & 0,3 & 553,7 & $7,0 \cdot 10^{-2}$ & 59 & $4,7 \cdot 10^{-5}$ & 0,54 \\
\hline 10 & 273,6 & 0,3 & 553,7 & $7,0 \cdot 10^{-2}$ & 65 & $8,6 \cdot 10^{-7}$ & 0,49 \\
\hline 11 & 300 & $-0,1$ & 607,2 & $8,0 \cdot 10^{-2}$ & 65 & $4,6 \cdot 10^{-5}$ & 0,49 \\
\hline 12 & 266,2 & $-0,1$ & 607,2 & $8,0 \cdot 10^{-2}$ & 72 & $5,1 \cdot 10^{-7}$ & 0,44 \\
\hline 13 & 300 & $-0,6$ & 684,4 & $9,3 \cdot 10^{-2}$ & 72 & $8,1 \cdot 10^{-5}$ & 0,44 \\
\hline 14 & 256,4 & $-0,6$ & 684,4 & $9,3 \cdot 10^{-2}$ & 80 & $6,7 \cdot 10^{-7}$ & 0,37 \\
\hline 15 & 300 & $-1,3$ & 800,7 & $1,1 \cdot 10^{-1}$ & 80 & $3,1 \cdot 10^{-4}$ & 0,37 \\
\hline 16 & 229,8 & $-1,3$ & 800,7 & $1,1 \cdot 10^{-1}$ & 91 & $7,9 \cdot 10^{-7}$ & 0,29 \\
\hline 17 & 300 & $-2,4$ & 1045,2 & $1,4 \cdot 10^{-1}$ & 91 & $5,4 \cdot 10^{-3}$ & 0,29 \\
\hline 18 & 141,7 & $-2,4$ & 1045,2 & $1,4 \cdot 10^{-1}$ & 110 & $9,7 \cdot 10^{-7}$ & 0,14 \\
\hline 19 & 300 & $-5,7$ & 2212,8 & $2,3 \cdot 10^{-1}$ & 110 & $6,9 \cdot 10^{-1}$ & 0,14 \\
\hline
\end{tabular}

Let's present this case graphically at once to analyse it better.

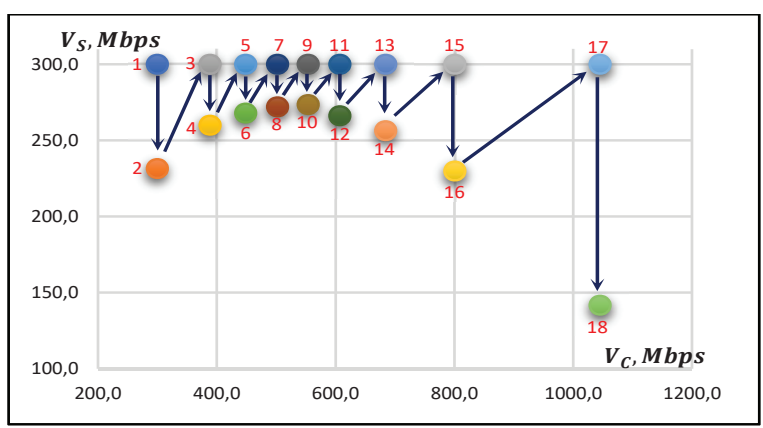

Fig. 4. Graphical display of the problem

The table above describes each transition between states when changing the parameters of the transmission system. It is possible to notice dependence of change of authenticity of transfer after coding and speed of a source of messages. First, unsatisfactory reliability at expansion and fixed speed of a source of messages, and then on the contrary satisfactory reliability at unfixed speed of a source.

It can be seen that at low initial energy, this technique failed to solve the problem according to the specified requirements.

When analysing Table 14 and Fig. 4, we can see that there is some limit after which the implementation of cyclical steps (described in paragraph 2) the situation only worsens and it is impossible to achieve both requirements.

Considering Table 14, it should be noted 11 the state of the transmission system, when the energy of the communication channel becomes very small. When expanding the frequency resource to $607,2 \mathrm{Mbps}$, the signal-to-noise ratio in the number of times is less than 1 , namely $h^{2}=0,988$ times. In other words, in this state, when finding the parameters of the new code when going to state 12 , the parameter of the speed of the message source begins the dynamics of deterioration.

The energy limit in this study can be considered the signal-to-noise ratio equal to $h^{2}=0 d B$ or $h^{2}=1$ time. Further cyclic steps described in this study do not make sense when the energy level is $h^{2}<0$.

\section{Conclusions}

For the first time, a method for selecting coding parameters during the spectrum expansion procedure and under the condition of constancy of the message source speed is proposed. Known methods for the synthesis of block code parameters were intended to keep unchanged the spectral-energy characteristics of radiation $[5,8,13]$. 
The algorithm of actions presented in this work provides fulfilment of requirements to reliability of information transfer at use of an additional frequency resource on condition of invariance of speed of a source of messages.

The initial parameters of the transmission system are very important for solving this problem. Better communication energy requires fewer actions to achieve results.

Research has shown that the use of this algorithm for the synthesis of block code parameters is not appropriate at low initial energy parameters of the transmission system, as a small margin may not be enough to meet the transmission requirements, and their further implementation is already beginning to reduce communication channel performance.

\section{References}

1. Fundamentals of telecommunications theory / Textbook / For general. ed. prof. Ilchenko M.Yu. - Kyiv: 2010. - ISSZI NTUU "KPI" - 786 p., ill.

2. Shannon C. E. A mathematical Theory of Communication [Text] / C. E. Shannon. - The Bell System Technical Journal, vol. 27., 1948. pp. 379-423, 623-656.

3. Urivsky L, Kornienko A, The method of determining the parameter of the encoding speed according to the algorithm for controlling the situation in the communication channel when the performance of the message source is unchanged. - $\mathrm{K} . \therefore$ ITS KPI. Igor Sikorsky, XV International STC "Prospects for Telecommunications", / Collection of materials. - 2021, p.p.62... 65.

4. George C. Clark Jr. J. Bibb Cain ErrorCorrection Coding for Digital Communications // eBook ISBN 978-1-4899-2174-1 // Springer US, 1981. $422 \mathrm{p}$.

5. Uryvsky L., Osypchuk S., Moshynska A., Pieshkin A. The Comparative Assessment of Corrective Parameters for Antinoise Convolutional and Block Codes / 2018
International Conference Radio Electronics \& Info Communications (UkrMiCo). - IEEE Xplore Digital Library. https://ieeexplore.ieee.org/xpl/conhome/904046 $0 /$ proceeding.

6. Cover T. M. Elements of Information Theory, 2nd ed. [Text] / T. M. Cover, J. A. Thomas. - Wiley-Interscience, 2006. - $772 \mathrm{p}$.

7. Gallager R. G. Information Theory and Reliable Communication [Text] / R. G. Gallager. -Wiley, 1968. - $588 \mathrm{p}$.

8. Uryvskiy L. Pieshkin A. The informational efficiency improving methods of the signal-code constructions with the condition of providing required reliability - Budapest, Hungary: The scientific heritage - № 11, 2017 - p.p. 72 ...77.

9. Uryvsky L., Pieshkin A. Assessment of Information Efficiency of Error-correcting Codes in Plotkin bound [Electronic resource] // IEEE International Conference on Information and Telecommunication Technologies and Radio Electronics. - 2017

10. Morelos-Zaragoza R. The Art of noisetolerant coding. Methods, algorithms, and applications / Per. from the English ed. V.B. Afanasiev. M. : Technosphere, 2005. $320 \mathrm{p}$

11. Hamming R. W. Coding and Information Theory, Prentice-Hall, Englewood Cliffs, N.J., 1986.

12. Uryvsky L., Prokopenko K., Peshkin A. The convolutional codes analysis technique on the optimum block codes grounds// Information and Telecommunication Sciences. - K.: NTUU 'KPI'. - 2014. - № 2, p.p.8-13.

13. Urivsky L., Peshkin A. Methods for assessing the marginal information efficiency of noise-tolerant codes // Information and Telecommunication Sciences, - $\mathrm{K}$.: NTUU 'KPI'. - 2016. - № 2. - p.p.70-74.

14. Peterson W. Error-correcting codes [Text] / W. Peterson, E. Weldon. // M .: "MIR", 1976. 594

Уривський Л.О., Корніснко А.А., Шмігель Б.О.

Аналіз спектральних характеристик каналу телекомунікації з блочним кодуванням за умов постійної швидкості джерела повідомлень

Проблематика. Напрямок розвитку сучасних систем електронних комунікацій має тенденцію до збільшення швидкості передачі інформації. У свою чергу, збільшення швидкості вимагає використання додаткових ресурсів каналу зв'язку і інструментів для підтримки заданої надійності передачі в умовах обмежених ресурсів. Однак використання ресурсів не $\epsilon$ безкоштовним. Тому виникає необхідність встановлення взаємозв'язку між умовами надійної передачі в високошвидкісних каналах і спектральними i енергетичними параметрами системи передачі інформації. 
Мета дослідження. Проаналізувати і описати вплив блочного завадостійкого кодування на швидкість передачі символів в каналі зв'язку, забезпечуючи при цьому необхідну надійність передачі інформації при постійній швидкості джерела повідомлення за рахунок збільшення задіяної смуги частот спектру.

Метод реалізації. Початковим етапом дослідження $є$ уявлення параметрів системи в разі недостовірної передачі. Потім синтезується надлишкова блоковий код, що забезпечує необхідну надійність передачі інформації, і виконується процедура розширення спектра при фіксованій швидкості джерела повідомлення.

Результати дослідження. Сформульовано рекомендації по способу вибору параметрів кодування в процедурі розширення спектра і при постійній швидкості джерела повідомлення.

Висновки. Аналіз можливостей завадостійкого кодування при різній енергетиці каналу зв'язку в умовах збільшення швидкості передачі в каналі при фіксованій швидкості передачі інформації джерела повідомлення.

Ключові слова: швидкість; джерело повідомлення; надійність; перешкодозахищеність.

Урывский Л.А., Корниенко А.А., Шмигель Б.О.

Анализ спектральных характеристик канала телекоммуникации с блочным кодированием при постоянной скорости источника сообщений

Проблематика. Направление развития современных систем электронных коммуникаций имеет тенденцию к увеличению скорости передачи информации. В свою очередь, увеличение скорости требует использования дополнительных ресурсов канала связи и инструментов для поддержания заданной надежности передачи в условиях ограниченных ресурсов. Однако использование ресурсов не является бесплатным. Поэтому возникает необходимость установления взаимосвязи между условиями надежной передачи в высокоскоростных каналах и спектральными и энергетическими параметрами системы передачи информации.

Цель исследования. Проанализировать и описать влияние блочного помехоустойчивого кодирования на скорость передачи символов в канале связи, обеспечивая при этом требуемую надежность передачи информации при постоянной скорости источника сообщения за счет увеличения задействованной полосы частот спектра.

Метод реализации. Начальным этапом исследования является представление параметров системы в случае недостоверной передачи. Затем синтезируется избыточный блочный код, обеспечивающий требуемую надежность передачи информации, и выполняется процедура расширения спектра при фиксированной скорости источника сообщения.

Результаты исследования. Сформулированы рекомендации по способу выбора параметров кодирования в процедуре расширения спектра и при постоянной скорости источника сообщения.

Выводы. Анализ возможностей шумоустойчивого кодирования при различной энергетике канала связи в условиях увеличения скорости передачи в канале при фиксированной скорости передачи информации источника сообщения.

Ключевые слова: скорость; источник сообщения; надежность; помехозащищенность. 